University of Nebraska - Lincoln

DigitalCommons@University of Nebraska - Lincoln

\title{
Impact of fire management on the ecology of collared lizard (Crotaphytus collaris) populations living on the Ozark Plateau
}

Jennifer A. Brisson

University of Nebraska-Lincoln, jennifer.brisson@rochester.edu

Jared L. Strasburg

Washington University, St. Louis

Alan R. Templeton

Washington University, St. Louis, temple_a@biology.wustl.edu

Follow this and additional works at: https://digitalcommons.unl.edu/bioscifacpub

Part of the Life Sciences Commons

Brisson, Jennifer A.; Strasburg, Jared L.; and Templeton, Alan R., "Impact of fire management on the ecology of collared lizard (Crotaphytus collaris) populations living on the Ozark Plateau" (2003). Faculty Publications in the Biological Sciences. 81.

https://digitalcommons.unl.edu/bioscifacpub/81

This Article is brought to you for free and open access by the Papers in the Biological Sciences at DigitalCommons@University of Nebraska - Lincoln. It has been accepted for inclusion in Faculty Publications in the Biological Sciences by an authorized administrator of DigitalCommons@University of Nebraska - Lincoln. 


\title{
Impact of fire management on the ecology of collared lizard (Crotaphytus collaris) populations living on the Ozark Plateau
}

\author{
Jennifer A. Brisson, Jared L. Strasburg, and Alan R. Templeton \\ Department of Biology, Washington University, St. Louis, Missouri 63130-4899, USA \\ Corresponding author - J. A. Brisson
}

\begin{abstract}
Eastern collared lizards (Crotaphytus collaris collaris) on the Ozark Plateau of southern Missouri are restricted to islands of rocky glade habitat located throughout the oak-hickory forests of the region. Human mediated suppression of fire negatively impacts collared lizard populations by permitting the overgrowth and consequent disappearance of this glade habitat and also leads to a dense forest understorey that impedes movement of lizards between glades. We present data examining the effects of a fire management regime on collared lizard populations we monitored via mark/recapture from 1998 to 2001. We demonstrate increased glade-to-glade dispersal, colonization of previously unoccupied glades, and a significant increase in population size in the burned area. In addition, we show that populations within burned areas exhibit body sizes similar to those reported for populations living on healthy habitat as compared to those living on habitat that has deteriorated because of fire suppression. We conclude that managed forest fires positively impact collared lizard populations in the Ozarks, promoting factors that increase the long-term sustainability of the species.
\end{abstract}

\section{Introduction}

Habitat disturbance due to human activity is an increasingly recognized phenomenon in natural populations (Saunders, Hobbs \& Margules, 1991). This disturbance frequently takes the form of habitat fragmentation, which isolates previously connected populations on habitat islands. Organisms living on such islands often experience a loss of genetic diversity, an increase in inbreeding and a decrease in population size. These factors in turn result in decreased population viability, increased sensitivity to environmental fluctuations and increased likelihood of population extirpation (Templeton et al., 1990; Saccheri et al., 1998; Debinski \& Holt, 2000). Isolation also prevents recolonization of habitat following local extirpation, further jeopardizing the long-term persistence of population complexes (Wilcox \& Murphy, 1985).

Eastern collared lizards, Crotaphytus collaris collaris (Iguanidae: Crotaphytinae), have undergone historic habitat fragmentation on the Ozark Plateau. After invading the Ozarks some 8000 years before present (ybp), they became isolated from the southwestern part of their range as a result of climatic cooling during the latter part of the Xerothermic (4000 ybp; Smith, 1957; Cole, 1971). These mediumsized, territorial predators are adapted to xeric conditions (Fitch, 1956; Bontrager, 1977), and thus live on habitat is- lands of rocky outcrops called glades scattered throughout the oak-hickory forests typical of the southern Missouri Ozarks (Erickson, Brenner, \& Wraight, 1942). Although the habitat requirements of the species predispose it to a fragmented distribution in the Ozarks (the northeastern limit of its range), there is evidence from genetic (Hutchison \& Templeton, 1999) and mark/recapture data (Templeton et al., 2001) that these animals are capable of dispersing through forests with a sparse understorey.

One of the primary threats to collared lizard glade habitat is human suppression of fire (Trauth, 1989; Templeton et al., 1990; Sexton, Andrews \& Bramble, 1992). In the absence of fire, eastern red cedars (Juniperus virginiana) are able to colonize glades and provide the shade necessary for recruitment of additional tree species (Ladd, 1991). Sexton et al. (1992) found that collared lizards living on glade habitat with observed red cedar recruitment exhibited decreased growth rates, decreased adult size and a shorter period of juvenile activity. Fire suppression also permits the growth of a thick understorey in forests surrounding glade habitat. This understorey impedes the dispersal of collared lizards to neighboring glades, even those within $50 \mathrm{~m}$ (Templeton et al., 1990, 2001). Consistent with this isolating effect, many Missouri Ozark populations of collared lizards exhibit extreme population subdivision (Templeton et al., 1990; Hutchison \& Templeton, 1999). 
A fire management regime has the potential to reverse these negative effects: fire can improve and expand glade habitat by removing vegetation and connect populations by clearing heavy forest undergrowth. Templeton et al. (2001) documented that collared lizard populations translocated into the Stegall Mountain Natural Area (southeastern Missouri), an area devoid of natural populations, displayed no interglade movement or colonization for 10 years after initial translocation. However, after a landscape-level fire management program was initiated, dispersal between glades and colonization of unoccupied glades began to occur. As the managed burn area was expanded, the pattern of no dispersal in unburned areas, followed by colonization of the area after it was included in the burn management program, was repeated.

The present study, performed at Taum Sauk Mountain State Park (80 km northeast of Stegall Mountain), represents, in part, a replicate study to confirm this impact of forest fires on lizard dispersal and colonization rates. However, this study introduces several novel aspects. First, unlike the Stegall Mountain area, natural populations have persisted on glades at Taum Sauk, and no translocations were performed at this site. Hence, the initial conditions in this case are not determined by intentional human intervention, but rather reflect a different and common initial condition in many conservation programs: remnant populations persisting in a degraded habitat.

Second, the Stegall Mountain studies documented the impact of fire management primarily with a temporal control, with comparisons being made before and after fire management was initiated. Our Taum Sauk studies have a component of temporal control as well; i.e., we studied dispersal and colonization within the burn management area for several consecutive years. However, about half of Taum Sauk Mountain was not incorporated into the fire management program. This unburned area also contains glades with remnant lizard populations, thereby allowing a spatial control to complement the temporal controls described by Templeton et al. (2001).

Third, we examine the body sizes of collared lizards in populations within the burned area and contrast them to those reported for populations living on healthy habitat and on habitat known to be severely degraded owing to fire suppression (Sexton et al., 1992). Templeton et al. (2001) did not address the impact of fire management upon individual body sizes.

\section{Methods}

\section{Study site}

We studied glade populations within Taum Sauk Mountain State Park, adjoining Missouri Department of Conservation (MDOC) land and private land in the Ozark Mountains of southeastern Missouri (Iron County). The site is dominated by oak-hickory forest, interspersed with rhyolitic rocky glade outcrops. Controlled burns were carried out at Taum Sauk in 1992, 1994, 1998 and 2001, and will be continued as a routine management practice by the Missouri Department of Natural Resources. This study focused on three main glade complexes within the burn management area (Figure 1): the Taum Sauk complex located in the north, the Mina Sauk complex in the middle and the New Mina Sauk complex in the south. Natural barriers separate these complexes, with small distances among glades within a complex and larger distances between glade complexes. Additionally, in 2000 and 2001 we monitored glades in two complexes outside of the burn management area, spread over a similar but somewhat smaller geographical area. The presence of a fire tower at this site, a thick understorey between glades and invasive red cedars on some glades suggests that fire has been suppressed in this area during the past 50 years. The MDOC knows of no fires in the area in at least the last 25 years, although no official records are available (M. Jones, MDOC, personal communication).

\section{Mark/recapture}

Lizards were located by visual survey from April or May to September or October in 1998, 1999, 2000 and 2001. Lizards were captured by noose or by hand. Snout-vent length (SVL) was measured to the nearest millimeter using a ruler, and mass was determined to the half gram using a $60 \mathrm{~g}$ or 100 g Pesola scale. We permanently and uniquely marked each lizard by toe clipping; lizards were also temporarily marked with a paint-pen, allowing us to identify without recapturing recently sampled lizards. Yearlings and older animals were sexed on the basis of a suite of strongly sexually dimorphic characters (body size, coloration, femoral pores, post-anal scales). Hatchlings were more difficult to sex, but males could be recognized at an early age by enlarged femoral pores and post-anal scales. Reproductive status of females was also recorded. Each lizard was released at its original point of capture after a maximum of 30 minutes handling. All glades monitored in this study were numbered as shown in Figure 1. Capture location was recorded for each lizard.

\section{Population size}

Population sizes were estimated using a Mathematica 4.0 (Wolfram, 1999) program written by A. R. Templeton (available upon request). This program uses the nonparametric methods of Chao, Lee \& Jeng (1992) to estimate population sizes from mark/recapture data when capture probabilities vary by time and individual and is described in more detail in Gerber \& Templeton (1996). Only animals that were yearlings or older were used in population size analyses.

\section{Body size}

We assigned animals to an age class each season such that an animal incremented to the next class following a winter of dormancy. Animals hatched in the fall of the season were hatchlings (age zero). Yearlings were animals in their first 


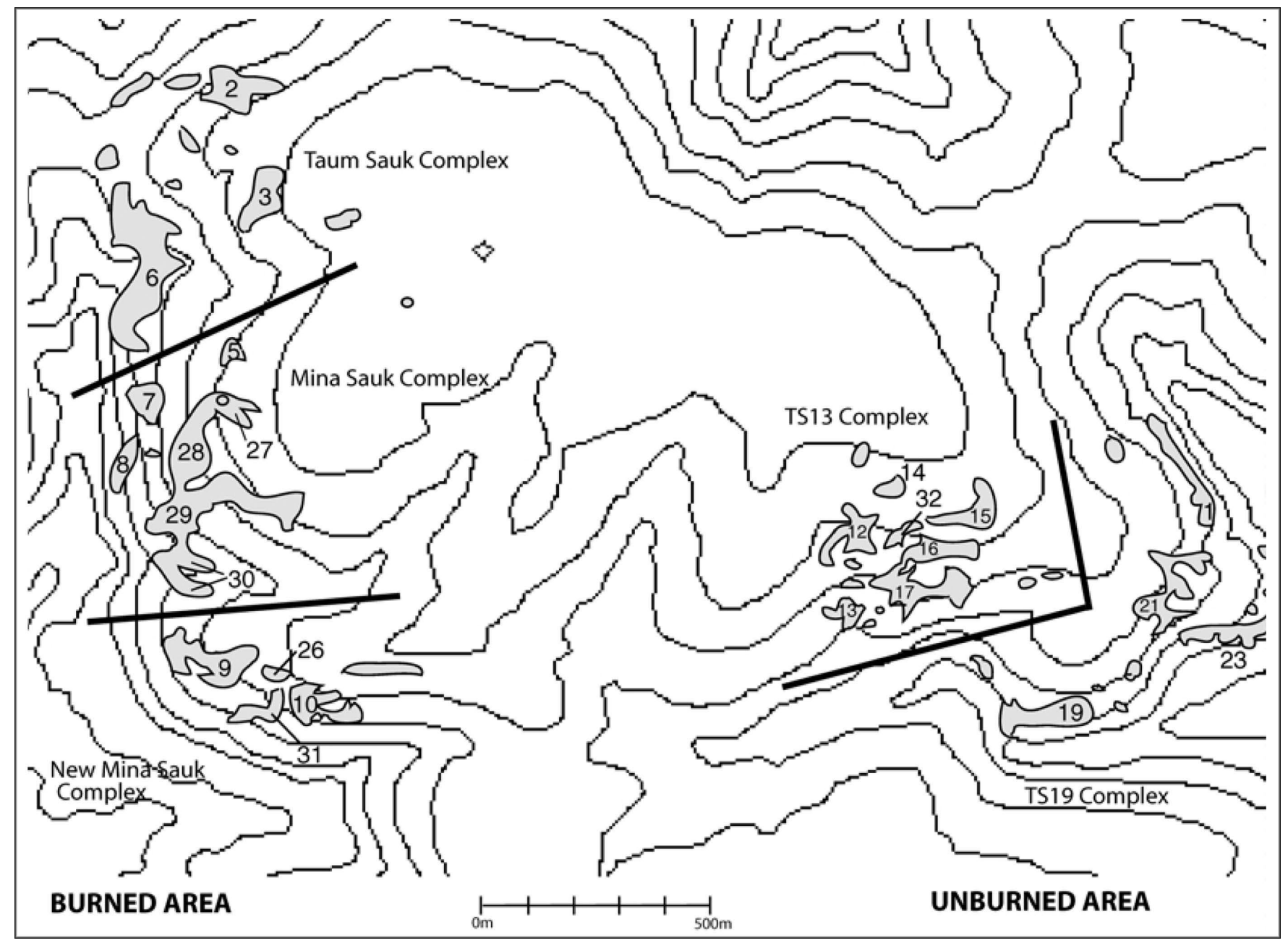

Figure 1. Map of the glades at Taum Sauk Mountain State Park. Numbered glades had collared lizards at some point during the study; glades without numbers were unoccupied. Glade complexes are separated by heavy black lines, and the burned and unburned sides are indicated.

full season (age 1). Yearlings typically become sexually mature during the season (Fitch, 1956; Ferguson, 1976; Trauth, 1978, 1979; Ballinger \& Hipp, 1985). Two-year- old lizards were animals in their second full season, etc. We averaged SVL across all individuals within each sex and age class. For animals with multiple measurements within an age class, the average of these measurements was used. Distributions of body sizes were tested for normality using a Shapiro-Wilk test prior to using $t$-tests to compare averages.

\section{Results}

\section{Capture statistics}

During the 4 years of this study, we marked 129 different individuals on glade complexes located within the burn area. We captured each lizard an average of 4.3 times. Most individuals $(64.7 \%)$ were caught at least twice, and the majority of the individuals caught only once $(71.1 \%)$ were hatchlings or yearlings caught early in the season (this group has relatively high mortality; Fitch, 1956). The maximum number of captures for a single lizard was 29. Sampling effort, as reflected by the number of days spent in the field per season and the number of captures per season, was consistent across years with the exception of 2000 (Table 1). Sex ratios did not differ significantly from 50:50 (Table 1). Glade complexes in the unburned area were monitored

Table 1. Capture data by year for burned and unburned glades

\begin{tabular}{lrrrr}
\hline & 1998 & 1999 & 2000 & 2001 \\
\hline Burned glades & 14 & 24 & 5 & 11 \\
$\quad$ Hatchlings & 6 & 12 & 22 & 21 \\
$\quad$ Yearlings & 18 & 15 & 24 & 32 \\
2 yr olds and older & $12: 12$ & $14: 13$ & $24: 22$ & $31: 22$ \\
$\quad$ Ratio of yearlings and & & & & \\
$\quad$ older, males:female & 21 & 17 & 7 & 15 \\
$\quad$ Number of days in field & 169 & 165 & 75 & 167 \\
$\quad$ Number of captures & - & - & 0 & 4 \\
Unburned glades & - & - & 5 & 22 \\
$\quad$ Hatchlings & - & - & 5 & 21 \\
$\quad$ Yearlings & - & - & $7: 3$ & $18: 25$ \\
$\quad$ 2 yr olds and older & & & & \\
$\quad$ Ratio of yearlings and & - & - & 3 & 9 \\
$\quad$ older, males:females & - & - & 12 & 104 \\
$\quad$ Number of days in field & Number of captures & - & &
\end{tabular}


in 2000 and 2001. On these complexes, we captured a total of 51 animals.

Sexton et al. (1992) reported emergence of collared lizards from hibernacula in early to mid-April, depending on weather conditions. We encountered yearlings and older animals on our earliest study date each season $(12 / 5 / 98$, $1 / 5 / 99,22 / 4 / 00,4 / 5 / 01)$. Yearlings and older lizards began to disappear for hibernation in mid to late August. Hatchlings emerged soon after, although some temporal overlap occurred each year despite the ability of adults to prey upon newly emerged hatchlings (Burt, 1928). Hatchlings were typically active until late September or early October $(10 / 10 / 98,25 / 9 / 99,18 / 9 / 00$, and 23/9/01 were the last sightings for each year; these were also the last dates we monitored the glades in each season because of increasingly lower rates of lizard activity as the season progressed, and as such, these results are biased early). We plotted SVL against date to illustrate the season of activity for the different age classes (Figure 2).

\section{Dispersals}

We defined a major dispersal to be movement between glade complexes and a minor dispersal to be movement between glades within a complex. The distinction between minor and major dispersal events was not necessarily the absolute distances traveled, but the amount that must have occurred through forest habitat. We documented seven major dispersals within the burned area, including individuals moving between the two most distantly separated complexes (the Taum Sauk and New Mina Sauk complexes). No major dispersals were recorded on the unburned side of the mountain.

We observed 46 total minor dispersals within the burn area. Many of these dispersal events were the same individual moving several times (six times over two seasons in one case). Overall, 29 of 85 lizards that were captured more than once were dispersers over a minor or major distance.
There was a trend towards more dispersal earlier in the season. We found a significant negative correlation (Kendall's $\tau=-0.4015$, 1-sided $P=0.043$ ) between time of year and interglade movement. The majority of the dispersals occurred within the first 2 months of the season-in May and June (Figure 3). Because we scored dispersals as occurring on the day of discovery, the correlation may be even stronger if the actual day of dispersal was known. This correlation was significant even without the inclusion of seven dispersal events that took place between the end of the season and the beginning of the next season (not included in Figure 3).

We also observed dispersal events on the unburned glade complexes. All 11 dispersals, however, were minor. Although there was a higher proportion of dispersing lizards on the burned side versus the unburned side $(34 \%$ versus $23 \%$ ), this difference was not significant (Fisher's Exact Test, 1-sided $P=0.11$ ). The lizards on the burned side tended, on average, to travel a longer distance than those on the unburned side (Table 2). This trend was significant for comparisons of the burned versus unburned areas for the 2000-2001 data $(t=1.90$, d.f. $=32$, 1-sided $P=0.033)$, as well as for all years of the burned area versus the 2 years of the unburned data $(t=1.79$, d.f. $=62$, 1 sided $P=0.039$ ).

\section{Colonization of new glades}

We documented the colonization of new glades in the burned area during this study. In 1998, there were eight occupied glades in the surveyed area. By the 2000 season, we found lizards on five additional glades in the burned area that were previously unoccupied (glades 7, 9, 10, 26, 31), four of which comprised a new glade complex (the New Mina Sauk complex, glades 9, 10, 26, 31). These included lizards marked from previous years on other glades as well as previously unmarked animals. By the 2001 season, the New Mina Sauk complex had 16 lizards, including two hatchlings in the autumn of 2001, and an additional glade in the Mina Sauk complex (glade 5) had been colonized.

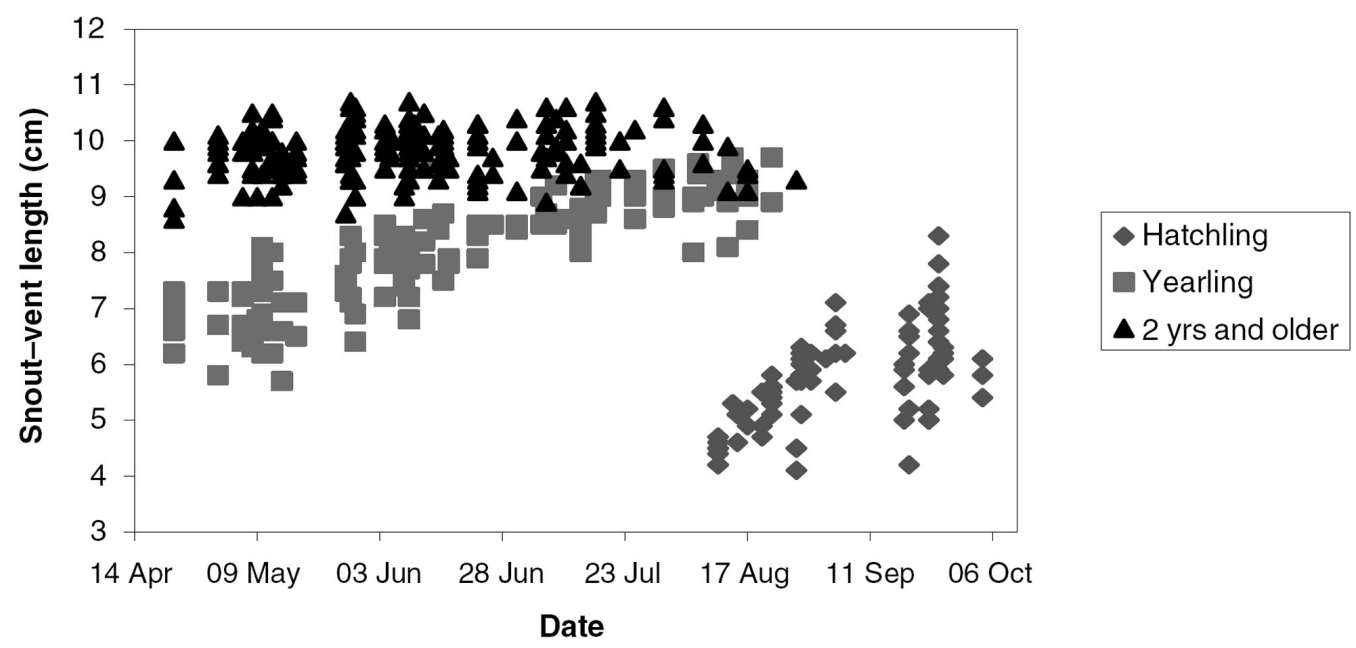

Figure 2. Plot of SVL by date $(N=410)$; data pooled across all seasons for populations in the burned area. 
Table 2. Summary of dispersal data.

\begin{tabular}{lrrrrr}
\hline Area & $\begin{array}{r}\text { Number of animals } \\
\text { caught more than once }\end{array}$ & $\begin{array}{r}\text { Number of animals } \\
\text { dispersing }\end{array}$ & $\begin{array}{r}\text { Total number } \\
\text { of dispersals }\end{array}$ & $\begin{array}{r}\text { Number of } \\
\text { major dispersals }\end{array}$ & $\begin{array}{r}\text { Average dispersal } \\
\text { distance in m (SD) }\end{array}$ \\
\hline Burned, all years & 85 & 29 & 53 & 7 & $320(300)$ \\
Burned, 2000-1 & 50 & 17 & 23 & 3 & $380(372)$ \\
Unburned, 2000-1 & 31 & 7 & 110 & 0 & $210(147)$ \\
\hline
\end{tabular}

Table 3. Collared lizard observed population sizes from mark/recapture data, estimated population sizes using the Chao et al. (1992) algorithm, and corresponding standard deviation (SD) of those estimates for populations on the three glade complexes within the burn area in 1998, 1999, 2000 and 2001. The New Mina Sauk complex population size was not estimated for 2000 owing to insufficient sampling.

\begin{tabular}{llrrr}
\hline Year & Area & Observed & Estimated & SD \\
\hline 1998 & Taum Sauk & 8 & 8 & 0.00 \\
1999 & Taum Sauk & 8 & 8 & 0.00 \\
2000 & Taum Sauk & 8 & 28 & 20.11 \\
2001 & Taum Sauk & 10 & 10 & 0.00 \\
1998 & Mina Sauk & 16 & 17 & 1.29 \\
1999 & Mina Sauk & 19 & 19 & 0.86 \\
2000 & Mina Sauk & 32 & 67 & 20.79 \\
2001 & Mina Sauk & 27 & 38 & 7.26 \\
2000 & New Mina Sauk & 6 & - & - \\
2001 & New Mina Sauk & 16 & 25 & 9.02 \\
1998 & Entire burned area & 24 & 24 & 0.63 \\
1999 & Entire burned area & 27 & 27 & 0.75 \\
2000 & Entire burned area & 46 & 103 & 28.96 \\
2001 & Entire burned area & 53 & 72 & 9.08 \\
\hline
\end{tabular}

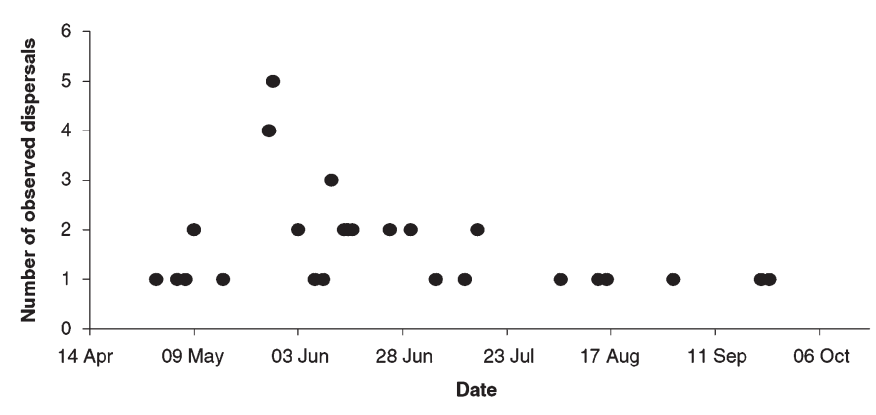

Figure 3. Movement of individual collared lizards in the burned area by month $(N=42)$; data pooled from all four seasons.

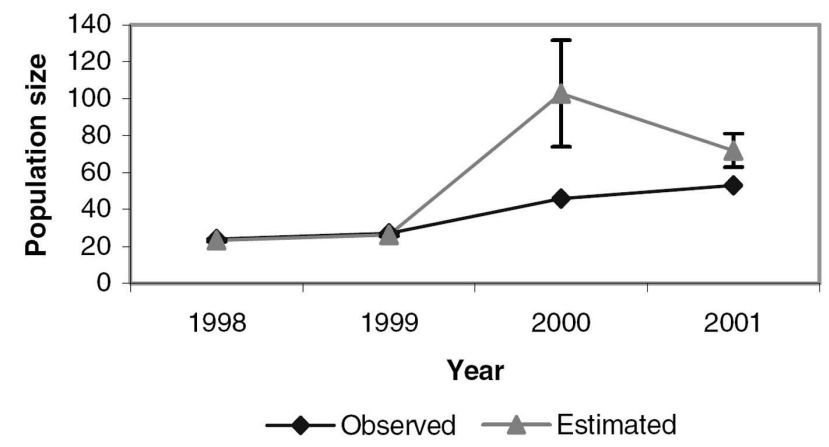

Figure 4. Total population size for the burned area by year, both observed and estimated. Error bars representing one standard deviation are included on the estimated population size line.

\section{Population sizes}

We estimated population sizes and corresponding standard deviations under the three different models given in Chao et al. (1992), and the estimate reported (Table 3) is the one associated with the highest estimated sample coverage, although all three estimates gave similar numbers.

The results for each year are presented in Table 3. Note that in 1998 and 1999, the observed and estimated population sizes were identical or almost identical for populations at both the Taum Sauk and Mina Sauk glade complexes (with very small standard deviations). This reflects the intense sampling in those 2 years that resulted in most individuals being caught multiple times. In 2000, sampling was less intensive, and since population size in this algorithm is estimated via sample coverage estimation (Chao et al., 1992), the estimated population size for this year is considerably larger (with a high standard deviation) than the observed numbers of lizards.

The total population size (all glade complexes within the burned area combined) increased dramatically from 1998 to 2001, more than doubling from an observed 24 (estimated 24) in 1998 to an observed 53 (estimated 72) in 2001 (Figure 4). The slope of the line representing this population growth for the observed population sizes was significantly different from zero $(t=12.49$, d.f. $=2$, 1 -sided $P=$ $0.003)$, and that for the estimated population sizes was significant as well $(t=3.94$, d.f. $=2$, 1 -sided $P=0.029)$.

\section{Body size}

We examined the average SVL data for all lizards that could be accurately aged to their year of birth. These averages for lizards in the burned area are presented in Table 4, along with a comparison to the SVL data of Sexton et al. (1992) for the collared lizards surveyed at Sandy Ridge, an area about $100 \mathrm{~km}$ northeast of Taum Sauk. The data of Sexton et al. (1992) in Table 4 were taken from their later sampling period, when the glade habitat was considered sub-optimal owing to successional changes resulting from fire suppression. As expected, the Taum Sauk lizards were generally larger than the Sandy Ridge lizards for this time period, especially in the younger age classes.

We also compared Taum Sauk burned area body-size data to the data of Sexton et al. (1992) from their 1960-65 sampling period (Table 5), when the glade habitat at Sandy Ridge was in a healthier condition. No significant differences were found, with the exception of 3-year-old males, an age group with a relatively small sample size. Overall, the body sizes of collared lizards in the burned area at Taum Sauk were more 
like those of the 1960-65 sampling period (healthy glade) at Sandy Ridge. Since we have only been monitoring the unburned area for two seasons, and since we could only reliably age hatchlings and yearlings caught early in the season, we did not have enough body-size data to make meaningful comparisons involving the unburned area lizards.

\section{Discussion}

The beneficial effects of prescribed burning have been documented for a wide variety of organisms (e.g., Reed, 1997; Menges \& Dolan, 1998), and managed fires can be an integral part of habitat restoration in the Ozarks (Ladd, 1991). A previous genetic analysis of collared lizard populations throughout the northeastern Ozarks showed no correlation between genetic and geographical distance, a pattern consistent with recent fragmentation of a previously genetically homogeneous population (Hutchison \& Templeton, 1999). This pattern also implies a general lack of gene flow that may have profound implications for the dynamics of extirpation and recolonization of local populations as well as genetic exchange between populations (MacArthur \& Wilson, 1967; Lacy, 1987; Higgins \& Lynch, 2001).

Since we began monitoring collared lizard populations at Taum Sauk in 1998, we have observed a sizeable number of dispersal events both within and between glade complexes. Most remarkably, we documented major dispersal events on the burned side. These major dispersal events, although relatively rare, may have a larger biological impact than minor dispersals since geographically distant glades are more likely to have different genetic variants than adjacent glades (Crow \& Kimura, 1970). In contrast to the burned area, we observed no major dispersals on the unburned side of the mountain.

Further, the predominant number of interglade movements occurred during the months of May and June, the time of mating activity (Fitch, 1956). This is a trend that has not previously been reported for the species. Male collared lizards establish and defend territories, but not until their second season. Yearling males often live within the terri-

Table 4. Comparisons between mean SVL in mm for different age classes of collared lizards in the burned area at Taum Sauk and at Sandy Ridge for the 1975-88 time period (poor-quality glade) as reported in Sexton et al. (1992). $N=$ number of observations. $P$-values are one-sided.

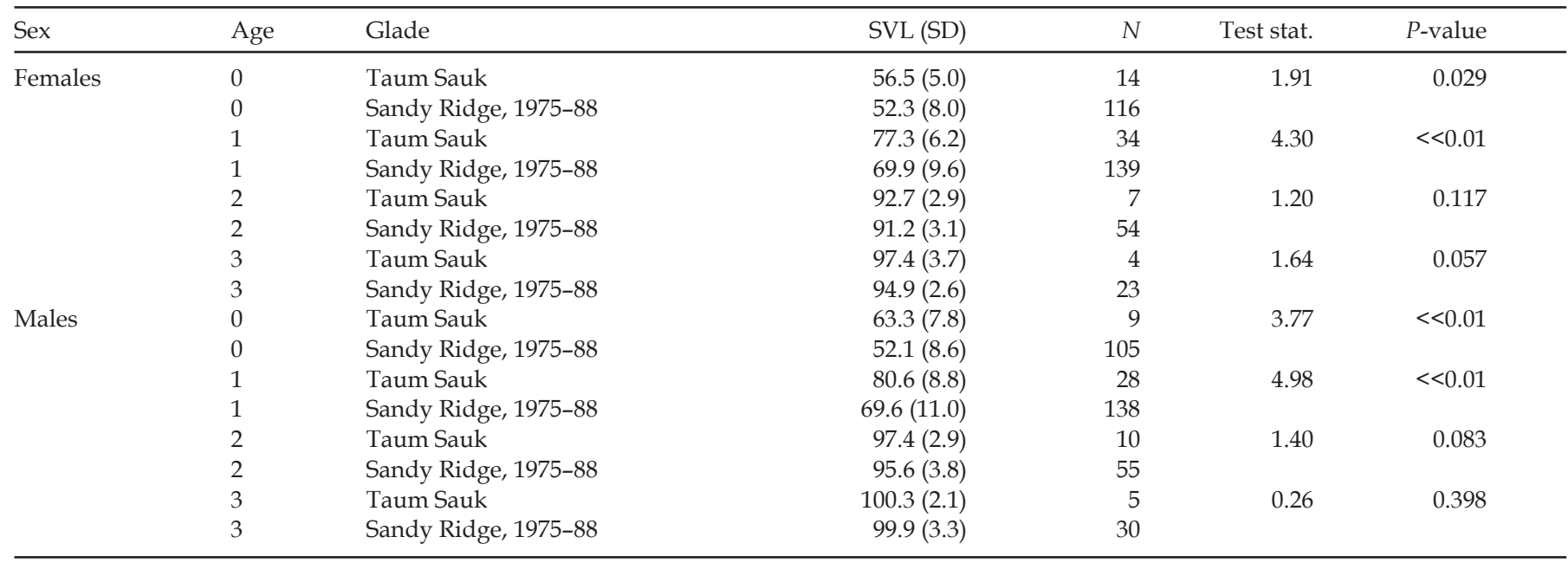

Table 5. Comparisons between mean SVL in $\mathrm{mm}$ for different age classes of collared lizards in the burned area at Taum Sauk and at Sandy Ridge for the 1960-65 time period (high-quality glade) as reported in Sexton et al. (1992). $N=$ number of observations. $P$-values are one-sided.

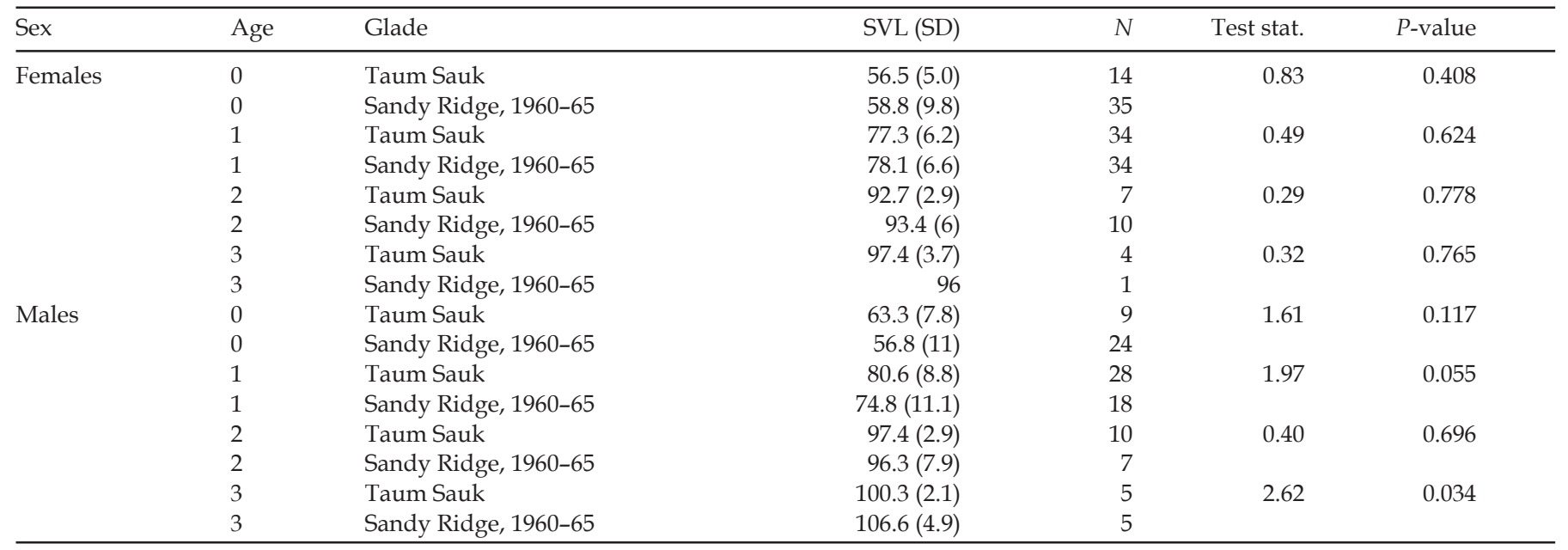


tories of older males, but do not freely breed despite physiological capability (Baird, Acree \& Sloan, 1996). The increased dispersal early in the season that we observed may represent the turnover of and competition for territories that accompany the transition of young males to breeding status, as well as the vying for territories prior to and during the mating season.

During our study we also observed the colonization of glades that were uninhabited in earlier years, including an entirely new glade complex (the New Mina Sauk complex, Figure 1). Access to new glades may allow younger lizards to escape inhibition by adult males. In fact, three of the yearling males found on the newly colonized glade complex dispersed there from the Mina Sauk complex. Whether this resulted in yearling males successfully breeding remains to be determined, although this was possible since sexually mature females are receptive to male yearlings and male yearlings more actively court females in the absence of older males (Baird \& Timanus, 1998). Also within the burned area, we observed lizards on glades that were too small to support viable populations in isolation (e.g., glade 26, Figure 1). These smaller glades may be useful as temporary habitat and may contribute to the overall capacity of the glade complex to support collared lizards when dispersal is possible. We have not found evidence of collared lizards on comparably sized glades in the unburned area.

The dispersals and colonization seen in our study population at Taum Sauk mirrored observations made at Stegall Mountain (Templeton et al., 2001). The spatial contrast here was qualitatively consistent with the temporal contrast at Stegall Mountain: managed burns of the intervening forest facilitate dispersal between glade populations. The similarity of the results shows that they are robust to the initial conditions: translocated populations surrounded by unoccupied habitat at Stegall versus remnant populations with many already inhabited glades at Taum Sauk. Thus, fire management has affected populations of collared lizards in a parallel manner at two independent sites in the Missouri Ozarks.

Finally, we demonstrated that the population of collared lizards examined here exhibited body sizes that are similar to those reported by Sexton et al. (1992) for a population of collared lizards living on a healthy glade, and significantly larger than for collared lizards living on habitat that had degraded owing to fire suppression. Interestingly, although body sizes for all age classes of lizards within the burn area at Taum Sauk were larger than those for the 1975-88 time period (degraded habitat) of Sexton et al. (1992), the body sizes were only significantly larger for hatchlings and yearlings. These data may indicate that the quality of the habitat and availability of food and activity areas was a more limiting factor for growth when the lizards were growing fastest.

In conclusion, fire management promotes factors favoring the long-term persistence of collared lizards, which are listed on Missouri's Species of Conservation Concern
Checklist (Missouri Natural Heritage Program, 2001). An appropriate conservation program must take into account specific ecological, life-history and population structure characteristics due to their relevance to the distribution of genetic diversity in a species (Nigh et al., 1992). Evidence presented here suggests that the increased interconnectedness and size of populations in burned areas, as well as the increase in available glade habitat, will aid in the conservation of collared lizards (and their genetic variation) by buffering local populations from extirpation and allowing gene flow among populations. This, in turn, will contribute to the long-term health and sustainability of these populations.

A variety of other desert-adapted plants and animals are restricted to glade habitat in the Ozarks, and these organisms are also threatened by glade fragmentation and deterioration that has resulted from fire suppression (Gerber \& Templeton, 1996). Future studies will be important in determining the broader role of fire management in the restoration of glade-endemic flora and fauna of the Ozark Mountain region.

\section{Acknowledgments}

We thank the many people who helped in capturing collared lizards for this work, including Margaret Lutz, Richard Glor and Jeff Templeton. We also thank two anonymous reviewers for their helpful comments. This work was supported by National Science Foundation grant DEB9610219 to ART and Nature Conservancy and Department of Conservation grants to JAB and JLS. JAB and JLS are Howard Hughes Medical Institute Predoctoral Fellows. We are grateful to the Missouri Department of Natural Resources and the Missouri Department of Conservation for their help and cooperation with this project.

\section{References}

Baird, T. A., Acree, M. A., \& Sloan, C. L. (1996). Age and genderrelated differences in the social behavior and mating success of free-living collared lizards, Crotaphytus collaris. Copeia 1996: 336-347.

Baird, T. A. \& Timanus, D. K. (1998). Social inhibition of territorial behavior in yearling male collared lizards, Crotaphytus collaris. Anim. Behav. 56: 989-994.

Ballinger, R. E. \& Hipp, T. G. (1985). Reproduction in the collared lizard, Crotaphytus collaris, in west central Texas. Copeia 1985: 976-980.

Bontrager, S. K. (1977). Autoecology of Crotaphytus collaris. PhD thesis, Oklahoma State University, Stillwater, OK.

Burt, C. E. (1928). Insect food of Kansas lizards with notes on feeding habits. J. Kansas Ent. Soc. 1: 50-68.

Chao, A., Lee, S. M., \& Jeng, S. L. (1992). Estimating population size for capture-recapture data when capture probabilities vary by time and individual animal. Biometrics 488: 201-216.

Cole, K. W. (1971). A consideration of macro-climatic and macrobiotic change in the Ozark Highlands during post-glacial times. Proc. Arkansas Acad. Sci. 25: 15-20. 
Crow, J. F. \& Kimura, M. (1970). An introduction to population genetic theory. New York: Harper \& Row.

Debinski, D. M. \& Holt, R. D. (2000). A survey and overview of habitat fragmentation experiments. Conserv. Biol. 14: 342-355.

Erickson, R. O., Brenner, L. G., \& Wraight, J. (1942). Dolomitic glades of east-central Missouri. Ann. Mo. Bot. Gard. 29: 89-101.

Ferguson, G. W. (1976). Color change and reproductive cycling in female collared lizards (Crotaphytus collaris). Copeia 1976: 491-494.

Fitch, H. S. (1956). An ecological study of the collared lizard (Crotaphytus collaris). Univ. Kans. Pub. Mus. Nat. Hist. 8: 213-274.

Gerber, A. S. \& Templeton, A. R. (1996). Population size and within-deme movement of Trimerotropis saxatilis (Acrididae), a grasshopper with a fragmented distribution. Oecologia 105: 343-350.

Higgins, K. \& Lynch, M. (2001). Metapopulation extinction caused by mutational accumulation. Proc. Natl. Acad. Sci. USA 98: 2928-2933.

Hutchison, D. W. \& Templeton, A. R. (1999). Correlation of pairwise genetic and geographic distance measures: inferring the relative influences of gene flow and drift on the distribution of genetic variability. Evolution 53: 1898-1914.

Lacy, R. C. (1987). Loss of genetic diversity from managed populations: interacting effects of drift, mutation, immigration, selection, and population subdivision. Conserv. Biol. 1: 143-158.

Ladd, D. (1991). Reexamination of the role of fire in Missouri oak woodlands. In Oak woods management workshop: pp. 67-80. Charleston: Eastern Illinois University.

MacArthur, R. H. \& Wilson, E. O. (1967). The theory of island biogeography. Princeton: Princeton University Press.

Menges, E. S. \& Dolan, R. W. (1998). Demographic viability of populations of Silene regia in Midwestern prairies: relationship with fire management, genetic variation, geographic location, population size, and isolation. J. Ecol. 86: 63-78.

Missouri Natural Heritage Program (2001). Missouri species of conservation concern checklist. Jefferson City: Missouri Department of Conservation.

Nigh, T. A., Pflieger, W. L., Redfearn, Jr., P. L., Schroeder, W. A., Templeton, A. R., \& Thompson III, F. R. (1992). The Biodiversity of Missouri. Jefferson City: Missouri Department of Conservation.
Reed, C. C. (1997). Responses of prairie insects and other arthropods to prescription burns. Nat. Areas J. 17: 380-385.

Saccheri, I., Kuussaari, M., Kankare, M., Vikman, P., Fortelius, W., \& Hanski, I. (1998). Inbreeding and extinction in a butterfly metapopulation. Nature 392: 491-494.

Saunders, D. A., Hobbs, R. J., \& Margules, C. R. (1991). Biological consequences of ecosystem fragmentation: a review. Conserv. Biol. 5: 18-32.

Sexton, O. J., Andrews, R. M., \& Bramble, J. E. (1992). Size and growth rate characteristics of a peripheral population of Crotaphytus collaris (Sauria: Crotaphytidae). Copeia 1992: 968-980.

Smith, P. W. (1957). An analysis of post-Wisconsin biogeography of the Prairie Peninsula based on distributional phenomena among terrestrial vertebrate populations. Ecology 38: 205-218.

Templeton, A. R., Robertson, R. J., Brisson, J., \& Strasburg, J. (2001). Disrupting evolutionary processes: the effect of habitat fragmentation on collared lizards of the Missouri Ozarks. Proc. Natl. Acad. Sci. USA 98: 5426-5432.

Templeton, A. R., Shaw, K., Routman, E., \& Davis, S. K. (1990). The genetic consequences of habitat fragmentation. Ann. Mo. Bot. Gard. 77: 13-27.

Trauth, S. E. (1978). Ovarian cycle of Crotaphytus collaris (Reptilia, Lacertilia, Iguanidae) from Arkansas with emphasis on corpora albicantia, follicular atresia, and reproductive potential. J. Herpetol. 12: 461-470.

Trauth, S. E. (1979). Testicular cycle and timing of reproduction in the collared lizard (Crotaphytus collaris) in Arkansas. Herpetologica 35: 184-192.

Trauth, S. E. (1989). Distributional survey of the eastern collared lizard, Crotaphytus collaris collaris (Squamata: Iguanidae), within the Arkansas River Valley of Arkansas. Proc. Arkansas Acad. Sci. 43: 101-104.

Wilcox, B. A. \& Murphy, D. D. (1985). Conservation strategy: the effects of fragmentation on extinction. Am. Nat. 125: 879-887.

Wolfram, S. (1999). Mathematica. Champaign: Wolfram Research, Inc. 